\title{
Growth and antioxidant response of juvenile oysters Crassostrea sikamea and Crassostrea corteziensis treated with Streptomyces strains
}

\author{
[Crescimento e resposta oxidative de ostras jovens Crassostrea sikamea $e$ \\ Crassostrea corteziensis tratadas com cultura Streptomyces] \\ M. García-Bernal ${ }^{1,2}$, R. Medina-Marrero ${ }^{1}$, Á.I. Campa-Córdova ${ }^{2}$, \\ J.M. Mazón-Suástegui ${ }^{2 *}$
}

${ }^{1}$ Centro de Bioactivos Químicos - Universidad Central de Las Villas - Villa Clara, Cuba

${ }^{2}$ Centro de Investigaciones Biológicas del Noroeste S.C - La Paz - Baja California Sur, México

\begin{abstract}
The effect of three Streptomyces strains (N7, RL8 and V4) and a mixture of Bacillus (BMix) on the growth (Weight, Size) and superoxide dismutase activity (SOD) in hatchery-reared juvenile oysters Crassostrea corteziensis and Crassostrea sikamea was investigated to determine their probiotic potential. Microorganisms were added to culture water at $1 \times 10^{6} \mathrm{CFU} / \mathrm{ml}$ once a day during 30 days and all oysters fed daily a microalgae mix. Juveniles of $C$. sikamea treated with strains N7, RL8 and V4 had a significant weight gain compared to the control group. $C$. corteziensis juveniles treated with strains RL8 and BMix showed a significantly higher weight gain than the control group. No significant size increase was observed in any treated group for both oyster species. SOD activity significantly increased in C. sikamea treated with RL8 and with RL8, N7 and BMix in C. corteziensis. Streptomyces strains RL8 and N7 emerge as promising probiotic agents to cultivate $C$. sikamea and $C$. corteziensis and may also be useful to other molluscs and marine invertebrates.
\end{abstract}

Keywords: actinomycetes, oyster, growth, probiotic effect, SOD activity

\section{RESUMO}

O efeito de três culturas Streptomyces (N7, RL8 e V4) e uma mistura de Bacillus (BMix) sobre o cresimento (Peso, Tamanho) e atividade superóxido dismutase (SOD) em ostras jovens Crassostrea corteziensis $e$ Crassostrea sikamea cultivadas artificalmente foi investigado para determinar seu potencial probiótico. Microorganismos foram adicionados à água de cultura a $1 \times 10^{6}$ CFU/ml uma vez por dia durante 30 dias e todas as ostras foram alimentadas diariamente com uma mistura de microalgas. Jovens $C$. sikamea tratados com culturas N7, RL8 e V4 tiveram ganho de peso significativo quando comparado ao grupo de controle. Jovens C. corteziensis tratados com culturas RL8 e BMix demonstraram peso significativamente mais algo que o grupo de controle. Nenhum aumento em tamanho foi observado em grupos tratados em ambas espécies. A atividade SOD foi significamente aumentada em C. sikamea treatado com RL8 e com RL8, N7 e BMix em C. corteziensis. Culturas Streptomyces RL8 e N7 surgem como agentes probióticos promissores para o cultivo de C. sikamea e C. corteziensis e podem ser úteis para outros moluscos animais marinhos invertebrados.

Palavras-chave: actinomyces, ostra, cresimento, efeito probiótico, atividade SOD

\section{INTRODUCTION}

Industrial-scale oyster production along the Pacific coast of Mexico began more than 40 years ago with the introduction of the Pacific oyster Crassostrea gigas (Thunberg, 1793), which is still the most extensively produced oyster species in this and in other countries

Recebido em 18 de dezembro de 2018

Aceito em 5 de junho de 2019

*Autor para correspondência (corresponding author)

E-mail: jmazon04@cibnor.mx worldwide. Other cultivated species are the Kumamoto oyster Crassostrea sikamea (Anemiya, 1928), initially introduced to Mexico as a variant to $C$. gigas, as well as the pleasure oyster Crassostrea corteziensis (Hertlein, 1951), a native species found from the Gulf of California to Panama, which is fairly abundant in Mexico's northwestern states of Sonora, Sinaloa and Nayarit states (Mazón-Suástegui et al., 2011). 
Recurrent disease outbreaks with high mortality rates of cultivated oysters are a major problem that seriously reduces mollusc production in many countries around the world (Pulvenis, 2014). These epidemics are commonly produced by mesophilic marine bacteria of the genus Vibrio, which affects larval and post-larval stages in seed-producing commercial hatcheries, as well as juveniles and adults grown-out in the field (Travers et al., 2015). For decades, these outbreaks have been treated in hatchery with antibiotics that, over time, increased the pathogenicity of many bacteria, reduced shellfish immune response, and left residual compounds in effluents that spread the problem to more distant locations (Zorriehzahra et al., 2016).

In the last few decades, more ecofriendly approaches such as the use of probiotics to control pathogenic bacteria that affect aquaculture have been extensively considered (Tan et al., 2016). Probiotics have become a valuable alternative to treat cultivated species because some bacterial strains are able to improve the growth rate, food conversion efficiency, tolerance to stress and immune response of fish and shellfish (Xia et al., 2014). Current scientific knowledge about the use of probiotics is less abundant in bivalve molluscs than in shrimp and marine fish, but growing interest and recent advances in this field are promising, particularly in larval and juvenile stages (Abasolo-Pacheco et al., 2016; 2017).

Marine Actinomycetes, mainly of the genus Streptomyces, are gram-positive bacteria that may produce antimicrobial secondary metabolites, contribute to the recycling of organic matter and excretion products (Ser et al., 2015), and produce heat and desiccation resistant spores (Chater et al., 2010). Consequently, Actinomycetes may be an alternative to control disease outbreaks in hatcheries, though very few studies to determine their probiotic effect in marine organisms, including bivalve molluscs, have been conducted (Das et al., 2010; GarcíaBernal et al., 2018).

The potential probiotic effect of Streptomyces sp. and Bacillus mix strains on the growth, survival, and antioxidant activity of superoxide dismutase enzyme is described in juvenile C. sikamea and $C$. corteziensis juveniles, two edible oyster species of high commercial value.

\section{MATERIALS AND METHODS}

The probiotic strains used in this study were Streptomyces strains. N7, RL8, and V4, isolated from marine sediment and selected in previous in vitro studies (García-Bernal et al., 2015); a Bacillus mixture (BMix), composed by Bacillus tequilensis YC5-2, Bacillus endophyticus C2-2, and B. endophyticus YC3-B (Luis-Villaseñor et al., 2011), belonging to CIBNOR's culture collection.

All microorganisms were cultivated in tryptone soy broth (TSB; \#236950, BD Difco, Franklin Lakes, NJ). Streptomyces strains were incubated by shaking at $30^{\circ} \mathrm{C}$ for 7 days and Bacillus strains were incubated at $35^{\circ} \mathrm{C}$ for $24-48$ hours. Cultures were centrifuged at $4696 \times \mathrm{g}$ for $10 \mathrm{~min}$ at $4{ }^{\circ} \mathrm{C}$, followed by discarding the supernatant and washing the pellet twice with sterile seawater. Streptomyces biomass was then resuspended in sterile seawater until an optical density of 1.0 was reached at $600 \mathrm{~nm}$ (Gopalakrishnan et al., 2014). Bacillus biomass was similarly treated until an optical density of 1.0 was reached at $540 \mathrm{~nm}$ (Luis-Villaseñor et al., 20152011). The resulting suspensions $1 \times 10^{9}$ $\mathrm{CFU} / \mathrm{ml}$ were further adjusted to $1 \times 10^{6} \mathrm{CFU} / \mathrm{ml}$ for each treatment and were correlated with colony forming unit (CFU) counts using tenfold dilutions and spread plating on tryptone soy agar (TSA).

The experiment complied with the Guidelines of the European Union Council (2010/63/EU) and the Mexican Government (NOM-062-ZOO1999) for the production, care and use of experimental animals, and with the ARRIVE guidelines. Healthy juvenile ostreid molluscs belonging to the species $C$. sikamea and $C$. corteziensis were obtained from Acuacultura Robles Company, Bahía de La Paz, Baja California Sur, Mexico. Animals were acclimatized for 7 days at the Experimental Laboratory of Molluscs of CIBNOR.

Juvenile $C$. sikamea $(17 \pm 1.20 \mathrm{~mm}$ shell length; $1.11 \pm 0.10 \mathrm{~g}$ wet weight) and $C$. corteziensis $(21 \pm 0.65 \mathrm{~mm}$ shell length; $0.83 \pm 0.14 \mathrm{~g}$ wet weight) were reared in a commercial hatchery. Oysters were kept in $4 \mathrm{~L}$ plastic containers filled with $1 \mathrm{~L}$ filtered $(1 \mu \mathrm{m})$ and UV-sterilized seawater, at $29 \pm 1^{\circ} \mathrm{C}$ and $37 \mathrm{~g} / \mathrm{l}$ of salinity with constant aeration. Containers were placed in 
large fiber glass tanks operating as recirculating water bath systems to maintain a constant temperature. Containers held 450 oysters divided into 5 treatments of 30 oysters each, with were managed in triplicate. The treatments consisted of (i) Streptomyces strain V4; (ii) Streptomyces strain RL8; (iii) Streptomyces strain N7; (iv) BMix (1:1:1 ratio) and (v) Control (without probiotics and only fed a microalga mix, as described below). Containers were drained daily, washed and refilled with clean, sterilized seawater. All groups received the microalgae diet first and the bacterial strain $15 \mathrm{~min}$ thereafter. Treatments were added daily to each container for 30 days.

Two commercial microalgae Isochrysis galbana (v. affgalbana) and Chaetoceros calcitrans, obtained from CIBNOR's collection, were used as food for oysters. Microalgae were cultured in accordance to traditional and standardized methods at CIBNOR laboratory. The diet was provided daily at $1: 1$ ratio estimated by cell count, and a density of $70-80 \times 10^{3}$ cells $/ \mathrm{ml}$. At the end of the trial, growth and survival of oysters were recorded for each treatment. With these data, the absolute growth and weight $(\mathrm{mm}$ and $\mathrm{g}$, respectively) as well as the survival rate for each treatment was determined at the end of the trial.

Superoxide dismutase (SOD) activity was determined at the end of the experiment (30 days). The soft tissue from six juvenile oysters collected per each of three replicas per experimental group was excised and homogenized $(100 \mathrm{mg})$ in $500 \mu \mathrm{l}$ buffered phosphate ( $\mathrm{pH} 7.5)$, using a tissue homogenizer. The homogenate was centrifuged at $9327 \times \mathrm{g}$ for $10 \mathrm{~min}$ at $4^{\circ} \mathrm{C}$. The supernatant was stored at - $20^{\circ} \mathrm{C}$ until used. Superoxide dismutase (SOD) activity was measured using a commercial kit (\#19160, Sigma-Aldrich, St. Louis, MO). Results were expressed as an indirect measure of the SOD activity by the percentage reaction inhibition rate of the formation of WST-1 Formazan complex (Dudone et al., 2009).

Normality was initially analyzed with the Kolmogorov-Smirnov test and then confirmed with the Levene test for homogeneity of variance (Sokal and Rohlf, 2000). Thereafter, one-way ANOVA was used to assess differences in the growth and SOD activity among experimental groups. The percentage data (SOD) were arcsine transformed before the ANOVA analysis. Differences were considered significant at $\mathrm{P}<$ 0.05. The analysis was performed using SPSS statistics (v 21 for windows; SPSS Inc., Chicago Il.).

\section{RESULTS AND DISCUSSION}

Different responses in weight gain (WG), size increase (SI) and survival rate (SR) of $C$. sikamea and $C$. corteziensis juveniles were attained when treated with three different Streptomyces strains and the BMix mixture (Table 1). C. sikamea oysters treated with V4, RL8 and N7 had a significant WG, compared to the control group and BMix, $(\mathrm{P}<0.05)$. A significant weight gain also occurred in C.corteziensis treated with RL8 and BMix $(\mathrm{P}<$ 0.0 5), but not with V4 and $\mathrm{N} 7$ ( $\mathrm{P}>0.05)$. No significant size increase occurred between probiotic treated groups and the control group (P> 0.05) for both oyster species (Table 1). There was no mortality associated to any probiotic treatment during the 30 day trial.

Table 1. Effect of Streptomyces strains N7, RL8 and V4 and a Bacillus mixture (BMix) on growth parameters of C. sikamea and C. corteziensis juveniles

\begin{tabular}{lllllll}
\multirow{2}{*}{ Treatments } & C. sikamea & \multicolumn{5}{l}{ C. corteziensis } \\
\cline { 2 - 6 } & WG $(\mathrm{g})$ & SI $(\mathrm{mm})$ & SR $(\%)$ & WG $(\mathrm{g})$ & SI $(\mathrm{mm})$ & SR $(\%)$ \\
\hline V4 & $0.22 \pm 0.07^{\mathrm{a}}$ & $2.14 \pm 0.48^{\mathrm{a}}$ & $100 \pm 0.0$ & $0.10 \pm 0.05^{\mathrm{c}}$ & $0.13 \pm 0.38^{\mathrm{b}}$ & $100 \pm 0.0$ \\
RL8 & $0.28 \pm 0.05^{\mathrm{a}}$ & $1.54 \pm 0.77^{\mathrm{a}}$ & $100 \pm 0.0$ & $0.22 \pm 0.012^{\mathrm{a}}$ & $1.30 \pm 0.26^{\mathrm{a}}$ & $100 \pm 0.0$ \\
N7 & $0.29 \pm 0.03^{\mathrm{a}}$ & $2.06 \pm 0.13^{\mathrm{a}}$ & $100 \pm 0.0$ & $0.21 \pm 0.03^{\mathrm{ab}}$ & $1.18 \pm 0.13^{\mathrm{a}}$ & $100 \pm 0.0$ \\
BMix & $0.07 \pm 0.04^{\mathrm{b}}$ & $1.31 \pm 0.60^{\mathrm{a}}$ & $100 \pm 0.0$ & $0.23 \pm 0.02^{\mathrm{a}}$ & $0.33 \pm 0.19^{\mathrm{b}}$ & $100 \pm 0.0$ \\
Control & $0.06 \pm 0.02^{\mathrm{b}}$ & $1.21 \pm 0.50^{\mathrm{a}}$ & $100 \pm 0.0$ & $0.07 \pm 0.06^{\mathrm{bc}}$ & $0.78 \pm 0.07^{\mathrm{ab}}$ & $100 \pm 0.0$ \\
\hline
\end{tabular}

Note: Size Increase (SI), Weight Gain (WG) and Survival rate (SR). Data are expressed as mean \pm standard deviation. Means in the same column with different superscripts are significantly different $(\mathrm{P}<0.05)$. 
Probiotics have been associated with either weight increase or decrease in humans and animals (Angelakis et al., 2013). The efficacy of probiotics might be species dependent (Mohapatra et al., 2012) and dose dependent (Vine et al., 2006). In this study, Streptomyces strain RL8 significantly increased the weight of juvenile $C$. sikamea and $C$. corteziensis on the control group; this could be due to the ability of this genus to produce extracellular enzymes such as proteases, lipases and amylases (Barka et al., 2016). García-Bernal et al. (2015) showed that Streptomyces spp. RL8 and N7 produce hydrolytic enzymes that can improve the amylolytic and proteolytic activities in the digestive tract of aquatic organisms. CampaCordova et al. (2009) reported a growth increase in $C$. corteziensis juveniles with a daily dose of $5 \times 10^{4} \mathrm{CFU} / \mathrm{ml}$ of Lactobacillus sp. strain NS6.1, isolated from the lion-paw scallop Nodipecten subnodosus. The probiotic Lactobacillus acidophilus increased the weight and survival of pearl oyster, Pinctada margaritifera, spat

A

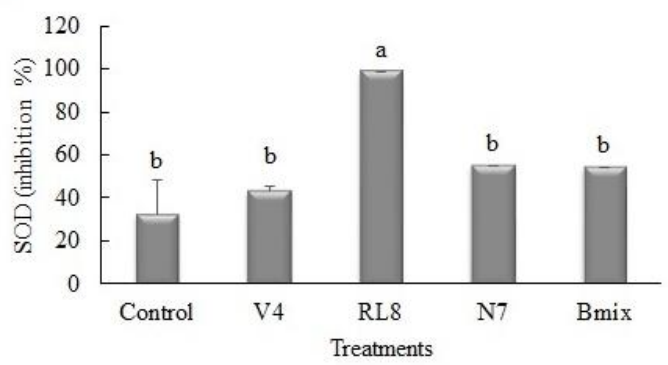

(Subhash and Lipton, 2007), whereas Pseudoalteromonas strain $\mathrm{X} 153$ reduced the weight of the king scallop Paralongidorus maximus Longeo (Longeo et al., 2004). AguilarMacias et al. (2010) reported that hatcheryreared Pinctada mazatlanica juveniles significantly increased growth and survival when provided daily with a Lactobacillus strain isolated from $N$. subnodosus at $1 \times 10^{6} \mathrm{CFU} / \mathrm{ml}$. According to Granados-Amores et al. (2012), Pseudomonas aeruginosa in combination with Burkholderia cepacia also beneficially influenced the growth and survival of $N$. subnodosus juveniles.

SOD activity in C.sikamea was only significantly higher $(\mathrm{P}<0.05)$ with the strain RL8, compared to the control group (Figure 1A). Strains N7, RL8 and BMix induced a significant increase $(\mathrm{P}<0.05)$ of SOD activity in $C$. corteziensis, in contrast to the strain V4 which significantly decreased SOD activity in this species (Figure 1 B).

B

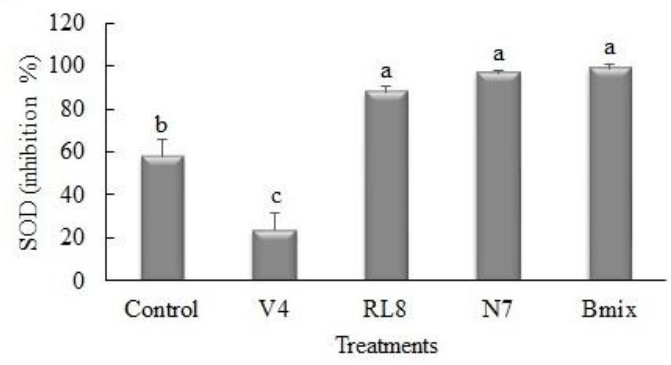

Figure 1. Superoxide dismutase (SOD) activity in (A) Crassostrea sikamea and (B) Crassostrea corteziensis juveniles after 30 day treatment with Streptomyces strains and a Bacillus mixture (BMix). Data are expressed as mean \pm standard deviation. Bars with different letters are significantly different $(\mathrm{P}<$ 0.05 ) from the control group.

Marine invertebrates, including mollusks, have developed an innate immune system, which mainly relies on phagocytosis and the generation of antimicrobial peptides and reactive oxygen species (Lemaitre and Hoffmann 2007). Because reactive oxygen species (ROS) (Dunone et al., 2009), mostly superoxide anions, also damage host tissues, invertebrates counteract their effect by means of the enzymes catalase, glutathione peroxidase and SOD (Fridovich, 1998). SOD facilitates the dismutation of superoxide radicals to form hydrogen peroxide, which is subsequently removed by catalase and glutathione peroxidase (Warner, 1994). SOD activity not only protects organism from superoxide anions but also from hydroxyl radicals, which are the most oxidant ROS (González and Arenas, 2002). Thus, tissue and hemolymph SOD activity can be used to measure the immune system competence and the immunomodulatory effect of bioactive substances and probiotics in mollusks (CampaCórdova et al., 2009).

A number of studies have suggested that some probiotics are effective in improving the non- 
specific immunity of aquaculture animals (Wang et al., 2008). The present study also confirmed these findings. In this study, maximum SOD activity was induced by the strain RL8 with significantly higher values in both oyster species, followed by N7 and BMix, which had greater activity in $C$. corteziensis. Thus, these strains may be used to protect animals from reactive oxygen species generated by infectious diseases or stress during intensive farming. AbasoloPacheco et al. (2017) showed that the action mechanism of probiotic strains is stage and strain specific, generating different responses by the host, including improved survival and growth (likely from better nutrient assimilation) and higher resistance against pathogens (possibly from strengthening the immune system.

Actinomycetes produce a wide array of antibiotics (Barka et al., 2016), which make them promising probiotic candidates in aquaculture. Yet, these microorganisms have been overlooked for this purpose, and very few studies have shown that the genus Streptomyces increased growth, survival, and resistance to disease in the giant tiger prawn Penaeus monodon (Das et al., 2010) and in the Litopenaus vannamei (GarcíaBernal et al., 2018). In our study, Streptomyces RL8 was the best performing strain among the other probiotics, as it significantly increased the weight and SOD activity of the two Ostreidae species of commercial and aquaculture interest; closely followed by Streptomyces N7 that increased the weight of $C$. sikamea and the SOD activity of $C$. corteziensis, as well as BMix that increased the weight and SOD of C. corteziensis.

\section{CONCLUSIONS}

Our study shows that the Streptomyces strains exert an overall probiotic effect on oysters by improving growth parameters and SOD activity. In addition, this is the first study showing the probiotic effect of actinomycetes strains in juvenile stages of two commercially valuable marine bivalves.

\section{ACKNOWLEDGEMENTS}

This study was financed by the Sectorial Fund for Education of Mexico: Project CB SEPCONACYT-258282 and Project PROINNOVACONACYT-241777. The authors gratefully acknowledge the support of the Cuban
Government and the technical staff at CIBNOR: Norma Ochoa, Pablo Monsalvo, Gabriel Robles, Delfino Barajas, Pablo Ormart, Guillermo García and Julián Garzón. We are also indebted to Acuacultura Robles Company (La Paz, B.C.S., Mexico) for providing oyster specimens. Ira Fogel of CIBNOR helped with editorial services.

\section{REFERENCES}

ABASOLO-PACHECO, F.; CAMPA-CÓRDOVA, A.I.; SAUCEDO, P.E. et al. Enhancing growth and resistance to Vibrio alginolyticus disease in catarina scallop (Argopecten ventricosus) with Bacillus and Lactobacillus probiotic strains during early development. Aquac. Res., v.4748, p.3042-305145974607, 2017.

ABASOLO-PACHECO, F; SAUCEDO, P.E.; MAZÓN-SUÁSTEGUI, J.M. et al. Isolation and use of beneficial microbiota from the digestive tract of lions-paw scallop Nodipecten subnodosus and winged pearl oyster Pteria sterna in oyster aquaculture. Aquac. Res., v.47,p.3042-3051, 2016.

AGUILAR-MACÍAS, O.L.; OJEDA-RAMÍREZ, J.J.; CAMPA-CÓRDOVA, A.I. et al. Evaluation of natural and commercial probiotics for improving growth and survival of the pearl oyster, Pinctada mazatlanica, during late hatchery and early field culturing. J. World Aquacult. Soc., v.41, p.447-454, 2010.

ANGELAKIS, E.; MERHEJ, V.; RAOULT D. Related actions of probiotics and antibiotics on gut microbiota and weight modification. Lancet Infect. Dis., v.13, p.889-899, 2013.

BARKA, E.A.; VATSA, P.; SANCHEZ, L. et al. Correction for Barka et al., taxonomy, physiology, and natural products of Actinobacteria. Microbiol. Mol. Biol. Rev., v.80, p.1-43, 2016.

CAMPA-CÓRDOVA, A.I.; GONZÁLEZ-OCAMPO, H.; LUNA-GONZÁLEZ, A. et al. Growth, survival, and superoxide dismutase activity in juvenile Crassostrea corteziensis (Hertlein, 1951) treated with probiotics. Hidrobiológica, v.19, p.151-157, 2009.

CHATER, K.F.; BIRO, S.; LEE, K.J. et al. Bacterial extracellular biology. FEMS Microbiol. Rev., v.34, p.171-198, 2010.

DAS, S.; WARD, L.R.; BURKE, C. Screening of marine Streptomyces spp. for potential use as probiotics in aquaculture. Aquaculture, v.305, p.32-41, 2010. 
DUDONNE, S.; VITRAC, X.; COUTIERE, P. et al. Comparative study of antioxidant properties and total phenolic content of 30 plant extracts of industrial interest using DPPH, ABTS, FRAP, SOD, and ORAC assays. J. Agric. Food Chem., v.57, p.1768-1774, 2009

FRIDOVICH, I. Oxygen toxicity: a radical explanation. J. Exp. Biol., v.201, p.1203-1209, 1998.

GARCÍA-BERNAL, M.; CAMPA-CÓRDOVA, A.I.; SAUCEDO, P.E. et al. Isolation and in vitro selection of actinomycetes strains as potential probiotics for aquaculture. Vet. World, v.8, p.170-176, 2015.

GARCÍA-BERNAL,M.; MEDINA-MARRERO, R.; RODRÍGUEZ-JARAMILLO, C. et al. Probiotic effect of Streptomyces spp. on shrimp (Litopenaeus vannamei) postlarvae challenged with Vibrio parahaemolyticus. Aquacult. Nutr., v.24, p.865-871, 2018.

GONZÁLEZ, M.; ARENAS, G. Characterization of immune response of the north scallop Argopecten purpuratus (Lamarck 1819) (Mollusca: Bivalvia). Cienc. Mar., v.28, p.247-255, 2002.

GOPALAKRISHNAN， S.; VADLAMUDI, S.; BANDIKINDA, P. et al. Evaluation of Streptomyces strains isolated from herbal vermicompost for their plant growth-promotion traits in rice. Microbiol. Res., v.169, p.40-48, 2014.

GRANADOS-AMORES, A.; CORDOVA, A.I.; ARAYA, R. et al. Growth, survival and enzyme activity of lions-paw scallop (Nodipecten subnodosus) spat treated with probiotics at the hatchery. Aquac. Res., v.43, p.1335-1343, 2012.

LEMAITRE, B.; HOFFMANN, J. The host defense of Drosophila melanogaster. Annu. Rev. Immunol., v.25, p.697-743, 2007.

LONGEO, A.; PEDUZZI, J.; BARTHELEMY, M. et al. Purification and partial identification of novel antimicrobial protein from marine bacterium Pseudoalteromonas species strain X153. Mar. Biotechnol., v.6, p.633-641, 2004.

LUIS-VILLASEÑOR, I.E.; MACÍAS-RODRÍGUEZ, ME.; GÓMEZ-GIL, B. et al. Beneficial effects of four Bacillus strains on the larval cultivation of Litopenaeus vannamei. Aquaculture, v.321, p.136144, 2011.

MAZÓN-SUÁSTEGUI, J.M.; RUÍZ-GARCÍA, M.C.; CHÁVEZ-VILLALBA, J. et al. Analysis of growth and first reproduction of hatchery-reared juvenile Cortez oyster (Crassostrea corteziensis) in northwestern Mexico: proposal of a minimal fishing size. Aquac. Res., v.42, p.1558-1568, 2011.
MOHAPATRA, S.; CHAKRABORTY, T.; PRUSTY, A.K. et al. Use of different microbial probiotics in the diet of rohu, Labeo rohita fingerlings: effects on growth, nutrient digestibility and retention, digestive enzyme activities and intestinal microflora. Aquacult. Nutr., v.18, p.1-11, 2012.

PULVENIS, J.F. El estado mundial de la pesca y la acuicultura (SOFIA). Topics Fact Sheets. Roma: Departamento de Pesca y Acuicultura de la FAO, 2014. Available in: <http://www.fao.org/fishery/sofia/es>. Accessed in: 3 jun 2018.

SER, H.L.; ABMUTALIB, N.S.; YIN, W.F. et al. Evaluation of antioxidative and cytotoxic activities of Streptomyces pluripotens MUSC 137 isolated from mangrove soil in Malaysia. Front Microbiolol., v.6, p.1398, 2015.

SOKAL, R.R.; ROHLF, F.J. Biometry: the principles and practice of statistics in biological research. 4.ed. New York: WH Freeman and Co., 2000. 937p.

SUBHASH, S.K.; LIPTON, A.P. Effects of a probiotic bacterium, Lactobacillus acidophilus, on the growth and survival of pearl oyster (Pinctada margaritifera) Spat. Isr. J. Aquacult., v.59, p.201-205, 2007.

TAN, L.T.; CHAN, K.G.; LEE, L.H.; GOH, B.H. Streptomyces bacteria as potential probiotics in aquaculture. Front. Microbiol., v.7, p.79, 2016.

TRAVERS, M.A.; BOETTCHER, M.K.; ROQUE, A.; FRIEDMAN, C.S. Bacterial diseases in marine bivalves. J. Invertebr. Pathol., v.131, p.11-31, 2015.

VINE, N.G.; LEUKES, W.D.; KAISER, H. Probiotics in marine larviculture. FEMS Microbiol. Rev., v.30, p.404-427, 2006.

WANG, Y.B.; LI, J.R.; LIN, J. Probiotics in aquaculture: challenges and outlook. Aquaculture, v.281, p.1-4, 2008.

WARNER, H.R. Superoxide dismutase, aging, and degenerative disease. Free Radic. Bio. Med., v.17, p.249-258, 1994.

XIA, Z.; ZHU, M.; ZHANG, Y. Effects of the probiotic Arthrobacter sp. CW9 on the survival and immune status of white shrimp (Penaeus vannamei). Lett. Appl. Microbiol., v.58, p.60-64, 2014.

ZORRIEHZAHRA, M.J.; DELSHAD, S.T.; ADEL, M. et al. Probiotics as beneficial microbes in aquaculture: an update on their multiple modes of action: a review. Vet. Q., v.36, p.228-241, 2016. 